\title{
Alternative Low-cost Adsorbent for Water and Wastewater Decontamination Derived from Eggshell Waste: An Overview
}

\author{
J. Carvalho $\cdot$ J. Araujo $\cdot$ F. Castro
}

Received: 17 December 2009/Accepted: 21 December 2010/Published online: 7 January 2011

(C) Springer Science+Business Media B.V. 2011

\begin{abstract}
As the current global trend towards more stringent environmental standards, technical applicability and cost-effectiveness became key factors in the selection of adsorbents for water and wastewater treatment. Recently, various low-cost adsorbents derived from agricultural waste, industrial by-products or natural materials, have been intensively investigated. In this respect, the eggshells from egg-breaking operations constitute significant waste disposal problems for the food industry, so the development of value-added by-products from this waste is to be welcomed. The egg processing industry is very competitive, with low profit margins due to global competition and cheap imports. Additionally, the costs associated with the egg shell disposal (mainly on landfill sites) are significant, and expected to continue increasing as landfill taxes increase. The aim of the present review is to provide an overview on the development of low-cost adsorbents derived from eggshell by-products.
\end{abstract}

Keywords Eggshell by-products - Low-cost adsorbents . Adsorption - Wastewater treatment

J. Carvalho · J. Araujo

CVR-Centro para a Valorização de Resíduos, Campus de Azurém da Universidade do Minho, 4800-058 Guimarães, Minho, Portugal

J. Carvalho $(\bowtie) \cdot$ F. Castro

CT2M-Centre for Mechanical and Materials Technologies, Mechanical Engineering Department, Campos de Azurém da Universidade do Minho, 4800-058 Guimarães, Minho, Portugal e-mail: jcarvalho@cvresiduos.pt

\section{Introduction}

The presence of toxic contaminants in aqueous streams, arising from the discharge of untreated effluents into water bodies, is one of the most important environmental issues in the field of waste management $[1,2]$. With the rapid increase in population and growth of industrialization all around the world, quality of both surface and ground water is deteriorating day by day. Treatment of industrial wastewater is increasingly necessary with respect to international regulations which mandated the reduction of different compounds in the cleaned water. Various methods are available for the removal of toxic pollutants from water and wastewater including reverse osmosis, ion exchange, precipitation, electro-dialysis, adsorption etc. Among these, adsorption is by far the most versatile and widely used method for the removal of pollutants due to its high removal capacity and ease of operation at large scale. Various researchers have used different materials as adsorbents for the removal of toxic pollutants with its own advantages and limitations. Most of the past work has focused on the removal of higher concentrations of pollutants, relying on the more traditional and more expensive absorbents materials [3-7]. However, as the discharge regulations become more and more stringent, the importance of the low concentration pollutants is consequently becoming an essential issue. In this respect, the environmental issues surrounding the presence of color in effluent are becoming a challenging problem for dyestuff manufactures, finishers and paper-making industry. In addition, increasingly stringent colour standards are being enforced to reduce the quantity of color in effluent and finally in receiving water courses. There are well documented facts that the effluents of these industries are containing suspected carcinogenic materials which are posing serious 
hazard to aquatic living organisms. Thus, it is necessary to reduce and eliminate these life threatening compounds from wastewater before it is discharged [9-14]. Activated carbon has been the most versatile adsorbent for the removal of various compounds from aqueous solutions. However, high cost of activated carbon restricts its application, prompting an increased research interest into the production of low-cost alternatives to the commonly used activated carbon. Recently, various approaches have been studied for the development of cheaper and effective adsorbents. These low-cost adsorbents include natural materials, biosorbents, and waste materials resulting from industry and agricultural activities. These materials could be used as adsorbents for the removal of dyes and ions from solution. Some of the reported adsorbents include agricultural and poultry by-products (eggshell waste, bagasse pith, maize cob, hen feathers, rice husk, coconut shell), industrial waste products (waste carbon slurries, metal hydroxide sludge), clay materials (bentonite, kaolinite), zeolites, siliceous material (silica beads, alunite, perlite), biosorbents (chitosan, peat, biomass) and others (starch, cyclodextrin, cotton), microorganisms such as algae [7-17]. Chitosan has received considerable interest for heavy metals removal due to its excellent metal-binding capacities and low cost, as can be obtained for free from fishery wastes such as shrimp, lobster, and crab shells [18-22]. Natural zeolites also gained a significant interest, mainly due to their valuable properties such as ion exchange capability. Zeolites are aluminosilicates with $\mathrm{Si} / \mathrm{Al}$ ratios between 1 and infinite, having promising benefits such as cost efficiency and selective adsorption for water, wastewater, carbon dioxide, hydrogen sulfide and other pollutants [23-27]. Clay is one of other potential alternatives to activated carbon as well. Similar to zeolites, clay minerals are also important inorganic components in soil, available in abundance, having good sorption properties which come from their high surface area and exchange capacities. The negative charge on the structure of clay minerals gives clay the capability to attract metal ions. In recent years, there has been an increasing interest in utilizing clay minerals to remove not only inorganic but also organic molecules [28-33]. Industrial waste is also one of the potentially low-cost adsorbent for heavy metal removal. It requires little processing to increase its adsorptive capacity. Generally industrial wastes are generated as by-products. Since these materials are locally available in large quantities, they are inexpensive. Various types of industrial wastes such as waste slurry, lignin, iron(III) hydroxide, blast furnace waste and red mud, have been explored for their technical feasibility to remove heavy metals and dyes from contaminated water [34, 35]. Red mud, a by-product of aluminium industry obtained from bauxite processing has been extensively investigated for the removal of dyes, metals and chlorophenols [36-41]. The waste carbon slurry generated during liquid fuel combustion in fertilizer plants has been converted into a inexpensive absorbent by various authors, being fruitfully employed on the removal of reactive dyes, as malachite green, vertigo blue 49, orange DNA13, carbofuran pesticides, anionic surfactants and hexavelant chromium [4249]. Low rank coal, such as lignite, is capable of having ion exchange with heavy metals due to its carboxylic acid and phenolic hydroxyl functional groups. Other low-cost adsorbents, such as agricultural wastes, have been also extensively studied. Agricultural materials, particularly those containing cellulose presents potential adsorption ability for various pollutants. These materials being economic and eco-friendly, available in abundance, renewable nature and low cost are forefront candidates for water and wastewater decontamination. In the last several decades, various agricultural wastes have been explored as low-cost adsorbent. Some of them include the shells and/or stones of fruits like nuts, peanuts, olive wastes, almonds, apricots stones and cherries, wastes resulting from the production of cereals such as rice, maize, wheat and corn as well as sugar cane bagasse, de-oiled soya and coir pith. Peel, the outer protective layers of fruits or vegetables are also gaining attention as adsorbents for the removal of metals, dyes and pesticides. Several works refer the investigation and development of cheap adsorption methods for removal of Safranin-T, Reactofix Golden Yellow 3 RFN, Reactofix Navy Blue 2 GFN from wastewater using activate rice and wheat husk as adsorbents [50-52]. Bagasse fly ash, obtained from sugar industry, has also been used as inexpensive and effective adsorbent for the removal of malathion, lindane, DDD, DDE and metals from wastewater [53-55]. These agricultural waste materials have been used in their natural form or after some physical or chemical modification. Bottom ash, a waste of thermal power plants, and deoiled soya, have been employed for successful removal and recovery of various hazardous substances such as phenol red dye, carmoisine A, basic fuchsin, watersoluble azo dye (metanil yellow) from wastewaters [15, 56-67].

Although many research works have been done recently to find the potential of using various agricultural-derived alternative adsorbents, so far no efforts have been made to obtain an overview of a specific adsorbent derived from poultry by-products - the eggshell waste-in terms of their removal performance, adsorption capacity, and cost effectiveness. Additionally, despite the fact that industrial effluents contain several pollutants simultaneously, little attention has been paid to adsorption of pollutants from mixtures. Considering this, the aim of the present review is to provide an overview of the eggshell low-cost adsorbent, and future work will encompass the investigation of the 
adsorption process in real industrial effluents and also demonstrate the use of this inexpensive adsorbent at an industrial scale.

\section{The Ancient Activated Carbons}

Activated carbon is the generic term commonly used to describe the carbonaceous adsorbents which present a highly crystalline and extensively developed internal pore structure. A wide variety of activated carbon derived products is available, exhibiting markedly different characteristics depending on the raw material and activation technique. It is usually prepared from coal, coconut shells, lignite, wood chips, sawdust, paddy husk, among others, and it can be prepared using one of the two basic activation methods: physical and chemical [68-76]. Generally, the physical activation requires high temperature and longer activation time when compared to chemical activation. Nevertheless in chemical activation the activated carbons need a thorough washing to remove chemical agents. By chemical activation, predominantly powder products are obtained, being the form mostly used for wastewater and water treatments. Carbon is a substance that has a long history of being used to absorb impurities and is perhaps the most powerful absorbent known. Activated carbon is carbon which has a slight electro-positive charge added to it, making it even more attractive to chemicals and impurities. As the water passes over the positively charged carbon surface, the negative ions of the contaminants are drawn to the surface of the carbon granules. Activated carbons are complex products often classified on the basis of their behaviour, surface characteristics and preparation methods [77]. Powdered activated carbon (PAC) is the carbon in form of powders or fine granules less than $1.0 \mathrm{~mm}$ in size with an average diameter between 0.15 and $0.25 \mathrm{~mm}$, presenting a large surface to volume ratio and a small diffusion distance. PAC is made up of crushed or ground carbon particles, $95-100 \%$ of which will pass through a designated mesh sieve or sieve. Granular activated carbon (GAC), on the other hand, has a relatively larger particle size compared to PAC and consequently, presents a smaller external surface, the diffusion becoming an important factor. This class of carbons is preferred for the adsorption of gases as their rate of diffusion is faster. Granulated carbons are used for water treatment, deodorization and separation of components of the flow system. Common classifications also define other forms of activated carbon. Among them are the extruded activated carbon (EAC), which consists of extruded and cylindrical shaped products with diameters from 0.8 to $45 \mathrm{~mm}$, mainly used for gas phase applications due to their low pressure drop, high mechanical strength and low dust content; impregnated carbon containing several types of inorganic contaminants such as iodine, silver, cations such as $\mathrm{Al}, \mathrm{Mn}$, $\mathrm{Zn}, \mathrm{Fe}, \mathrm{Li}, \mathrm{Ca}$; Polymers coated carbon in which a porous carbon can be coated with a biocompatible polymer to give a smooth and permeable coat without blocking the pores. Finally activated carbon is also available in special forms such as cloths and fibers [77-80].

\section{Low-cost Adsorbents}

Although activated carbon is the commonly preferred adsorbent, its widespread use is restricted due to high cost. In order to decrease the cost of treatment, attempts have been studied for the development of cheaper and also effective adsorbents which could be able to replace the more costly activated carbon. In view of the high cost and tedious procedure for the preparation and regeneration of activated carbon there is continuing search for low cost potential adsorbents. Several works has focused on various natural solid supports, which are able to remove pollutants from contaminated water at low cost [81-92]. Cost is actually an important parameter for comparing the adsorbent materials. According to Bailey et al. [93], an adsorbent can be considered a low-cost one if it requires little processing, is abundant in nature or is a by-product or waste material resulting from another industry. Certain waste products from industrial and agricultural operations, natural materials and biosorbents represent potentially economical alternative adsorbents. Many of them have already been tested and proposed for dye and ions removal on water and wastewater decontamination.

\section{Adsorption Models}

It well known that the adsorption process of the different compounds of a fluid mixture which flows through a packed bed of an adsorbent porous material, is the basis of several important applications in chemical engineering, with special focus on contacting systems for industrial and municipal water and wastewater treatment. The adsorption capacity depends on several variables, such as the concentration of the pollutants, the $\mathrm{pH}$ of the medium, the contact time, and the accessibility of the pollutants to the inner surface of the adsorbent, which in turn depends on their size, among others [94]. The specific sorption mechanisms by which the adsorption takes place on the adsorbents are still not clear. This is because adsorption is a complex process depending on several interactions such as electrostatic and non-electrostatic (hydrophobic) interactions. Although advances have been accomplished in terms of sorption properties and kinetics, much work remains 
undone and is necessary to identify clearly the sorption mechanisms [95]. Predicting the rate at which adsorption takes place for a given system, is probably the most important factor in adsorption system design. When a given mass of an adsorbent and a waste stream are in contact for a sufficiently long time, equilibrium between the amount of adsorbed pollutant and the amount remaining in solution will be attained. Under this equilibrium state, the amount of the adsorbed material can be calculated through mass balance according to Equation (1):

$\frac{X}{M}=\left(C_{0}-C_{e}\right) \frac{V}{M}$

where $X / M$ is the mass of pollutant per mass of media (expressed as $\mathrm{mg}$ pollutant/g media), $C_{O}$ is initial pollutant concentration in solution, $C_{e}$ the concentration of the pollutant in solution after equilibrium has been reached, $V$ the volume of the solution to which the media mass is exposed, and $M$ the mass of the media [96-100].

Several kinetic models have described the reaction order of the adsorption systems based on solution concentration. Isotherm adsorption models have been used in waste stream treatment to predict the ability of a certain adsorbent to remove a pollutant down to a specific discharge value. These include first-order and second-order reversible ones, and first-order and second-order irreversible ones, pseudo-first-order and pseudo-second-order. The sorption isotherms represent the relationship between the amount adsorbed by a unit weight of solid sorbent and the amount of solute remaining in the solution at equilibrium [101]. The two commonly used isotherm models are the Langmuir and the Freundlich models. Both isotherm models have been shown to be suitable for describing short-term and mono component adsorption of metal ions by different biosorbents $[102,103]$. On the other hand, reaction orders based on the capacity of the adsorbent have also been studied, such as Lagergren's first-order equation, Redlich Peterson model and BET model [104]. Langmuir and Freundlich isotherm models are frequently used isotherm models for describing short term and mono component adsorption of metal ions by different materials [102-105].

\section{Thermodynamic Sorption Parameters}

The free energy change of sorption can be calculated by Equation (2).

$\Delta G^{0}=-R T \ln K$

where $\Delta G^{0}$ is standard free energy change, $R$ is the universal gas constant $(8.314 \mathrm{~J} / \mathrm{mol} / \mathrm{K}), T$ is the absolute temperature and $K$ is equilibrium constant. The apparent equilibrium constant of the biosorption, $K^{\prime}{ }_{C}$ is obtained from Equation (3).

$K_{C}^{\prime}=C$ (biosorbent) eq $/ C$ (solution)

where $C$ (adsorbent) eq and $C$ (solution) eq are the ion concentrations on the adsorbent and in the solution at equilibrium [100].

\section{The Eggshell and Eggshell Membrane}

The eggshell by-product represents approximately $11 \%$ of the total weight (approximately average $60 \mathrm{~g}$ ) of egg [106]. Eggs are used in enormous amounts by food manufacturers and restaurants and the shells are discarded as waste. It was reported that about $28 \%$ of all eggs produced are sent to commercial breaking operations for manufacturing egg products [107]. The eggshell byproduct which results from these breaking operations represents a significant waste for the processing industry as they are traditionally useless after the production of eggs and egg derivatives. Most of this waste is commonly disposed in landfills without any pretreatment. Occasionally, a few percentages of these byproducts are reused and applied as a fertilizer or feed additive because of their high nutrition contents such as calcium, magnesium and phosphorus [108]. On behalf of the bioresource recovery and reuse, many investigations have been conducted to explore useful applications for eggshells. The results of this research has shown that eggshells appears to be able to effectively adsorb certain heavy metals and organic compounds [109-114]. In fact, the porous nature of eggshell makes it an attractive material to be employed as an adsorbent. The eggshell typically consists of ceramic materials which are arranged in a threelayered structure, namely the cuticle on the outer surface, a spongy (calcareous) layer and an inner lamellar (or mammillary) layer [106, 115]. The spongy and mammillary layers form a matrix composed of protein fibers bonded to calcite (calcium carbonate), representing more than $90 \%$ of the material $[106,109]$. The two layers are also constructed in such a manner that there are numerous circular openings (pores). Each eggshell has been estimated to contain between 7,000 and 17,000 pores. On an average, the eggshell weighs 5-6 g, with remarkable mechanical properties of breaking strength $(>30 \mathrm{~N})$ and is $300-350 \mu \mathrm{m}$ thick. This structure plays a crucial role in protecting the contents of the egg from the microbial and physical environment and in controlling the exchange of water and gases throughout the shell. The outer surface of the eggshell is covered with a mucin protein that acts as a soluble plug for the pores in the shell. The cuticle is also permeable to gas transmission. 
The chemical composition of the eggshell has been reported as $94 \%$ calcium carbonate, $1 \%$ magnesium carbonate, $1 \%$ calcium phosphate and approximately $4 \%$ of organic matter [106]. The eggshell by-product is, thus, inevitably composed of calcium carbonate (eggshell) and eggshell membrane (ESM). The ESM is located between the egg white (albumen) and the shell. There are two shell membranes around the egg, a thicker outer membrane attached to the shell and a thinner inner membrane [114-116] as depicted in Fig. 1. Each of these membranes is composed of protein fibers that are arranged to form a semi-permeable membrane, producing an intricate lattice network of stable and water-insoluble fibers and has high surface area resulting in various applications such as adsorbent [111, 117-122] and supporting medium for enzymes immobilization [123-125].

\section{Results and Discussion}

Physical and Chemical Characterization of Eggshell Material

The data presented in Table 1 indicate the BET surface area, total pore volume, densities and porosity of eggshell and eggshell membrane and eggshell particles. Additionally, aiming at increasing the surface area, the eggshell material was subjected to a thermal process of calcination at a temperature of $1,000^{\circ} \mathrm{C}$ to promote the decomposition of calcium carbonate to calcium oxide and carbon dioxide. As can be seen, pore properties between eggshell and eggshell membrane are similar according to the data obtained from BET surface area and total pore volume. However, after calcination, surface area of eggshell particles and particle porosity increased. With respect to particle density, it is noted that of eggshell is significantly larger than that of eggshell membrane $\left(2.658 \mathrm{~g} \mathrm{~cm}^{-3}\right.$ compared to $1.405 \mathrm{~g} \mathrm{~cm}^{-3}$ ), revealing the crystalline structure of the shell, mainly composed of calcium carbonate in the form of calcite, which presents a density of $2.710 \mathrm{~g} \mathrm{~cm}^{-3}$ [126].

As described by Tullett [113] the eggshell membrane is mainly consisted of fibrous proteins indicating that the organic matrix of the eggshell membrane is not rigid like inorganic minerals. It would be expected to result in the more macropore structure in eggshell particles because of the intrinsic existence of pore canal [126]. Therefore, the porosity of eggshell was estimated to be larger than that of eggshell membrane as seen in Table 1.

The elemental analyses, presented on Table 2, revealed that contents of carbon and hydrogen of the eggshell membrane sample are larger than those of eggshell sample, revealing once more that the eggshell particle should be almost composed of carbonate minerals. This observation was also demonstrated by Tsai and co-workers [116] through the FTIR analyses. Accordingly, our results presented on Fig. 2 revealed that the most significant peak of intensity of eggshell particle was found at $1,417 \mathrm{~cm}^{-1}$, strongly associated with the presence of carbonate minerals within the eggshell matrix [126]. The other two observable peaks at about 713 and $875 \mathrm{~cm}^{-1}$, should be associated with the in-plane deformation and out-plane deformation modes, respectively, in the presence of calcium carbonate as described by Busca and Resini [127]. With respect to the eggshell membranes, as expectable, the presence of amines and amides were found, exhibiting significant peaks at intensity of $3,200-3,500,1,652$ and $1,385 \mathrm{~cm}^{-1}$, respectively [127].

\section{Applications of Eggshell Adsorbents}

The utilization of the eggshell and ESM by-products has started over 1,970 with the development of several studies aiming at the calcium supplement and other nutrition sources from the albumin, membrane and matrix of the eggshell, which was processed by crushing and milling to obtain fine particles (flours) for animal use [128]. Later on,

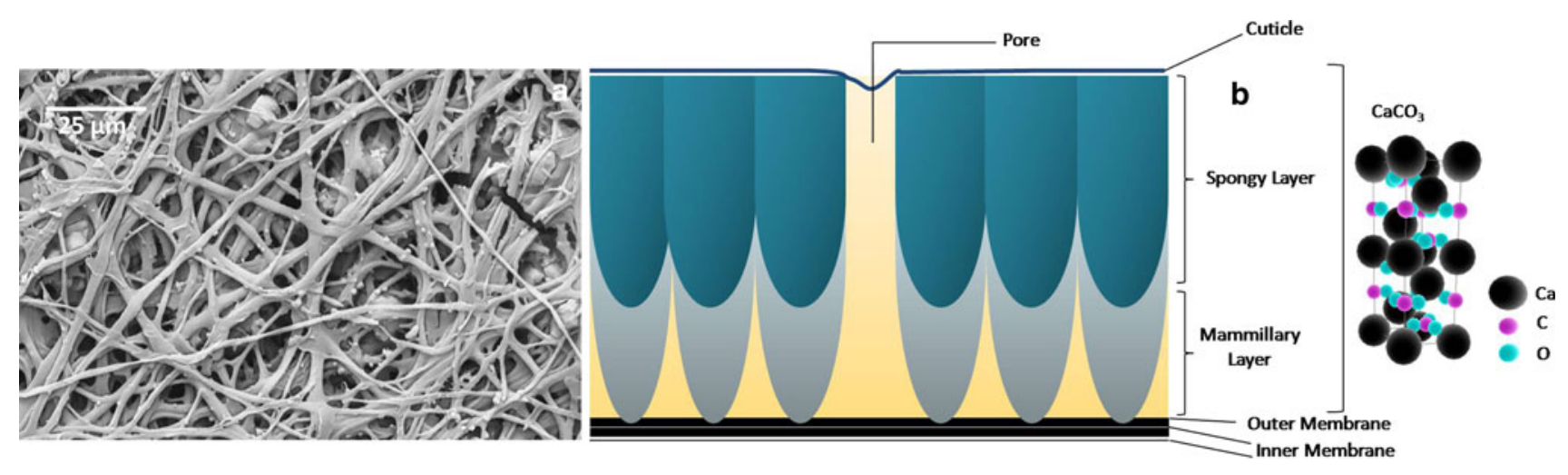

Fig. 1 Ultrastructural (a) and schematic (b) view of the eggshell 
Table 1 Chemical properties of eggshell, eggshell membrane and eggshell particles after calcination $\left(1,000^{\circ} \mathrm{C}\right)($ determined as Tsai et al. [116])

\begin{tabular}{llccc}
\hline Sample & $\begin{array}{l}\text { BET surface area } \\
\left(\mathrm{m}^{2} \mathrm{~g}^{-1}\right)\end{array}$ & $\begin{array}{l}\text { Total pore volume } \\
\left(\mathrm{m}^{3} \mathrm{~g}^{-1}\right)\end{array}$ & $\begin{array}{l}\text { Particle density } \\
\left(\mathrm{g} \mathrm{cm}^{-3}\right)\end{array}$ & $\begin{array}{l}\text { Particle porosity } \\
\left(\mathrm{g} \mathrm{cm}^{-3}\right)\end{array}$ \\
\hline Eggshell & $1.053 \pm 0.428$ & $0.0071 \pm 0.0032$ & 2.658 & 0.0182 \\
Eggshell membrane & $1.276 \pm 0.569$ & $0.0067 \pm 0.0047$ & 1.405 & 0.0093 \\
Eggshell after calcination $\left(1,000^{\circ} \mathrm{C}\right)$ & $1.845 \pm 0.278$ & - & - & 0.0510 \\
\hline
\end{tabular}

Table 2 Elemental analyses of eggshell and eggshell membrane particles (determined according to Tsai et al. [116])

\begin{tabular}{llll}
\hline Sample & $\begin{array}{l}\text { Carbon } \\
(\mathrm{wt} \%)\end{array}$ & $\begin{array}{l}\text { Hydrogen } \\
(\mathrm{wt} \%)\end{array}$ & $\begin{array}{l}\text { Oxygen } \\
(\mathrm{wt} \%)\end{array}$ \\
\hline Eggshell & $10.61 \pm 0.02$ & $0.71 \pm 0.04$ & $27.32 \pm 0.01$ \\
$\begin{array}{l}\text { Eggshell } \\
\text { membrane }\end{array}$ & $42.74 \pm 0.05$ & $6.45 \pm 0.01$ & $10.41 \pm 0.02$ \\
\hline
\end{tabular}

Rivera et al. [129] reported a novel procedure to produce porous hydroxyapatite from eggshells. Taking into account the sustainable utilization of eggshell and its intrinsic pore structure [130] the characterization of the biomaterial is very scarce in the literature. Creger et al. [131] observed the various stages of formation of the eggshell with scanning electron microscope. Garcia-Ruiz et al. [132] aimed at the textural analysis of eggshell with diffractometry techniques. It was found that the mineral structure of eggshell could be properly described in terms of competitive crystal (calcite) growth. The mineral phase (calcite) present in the eggshell was demonstrated and observed by X-ray diffractometry [129].

Considering the intrinsic pore structure of the eggshell, the available amounts and the bioresource recycling, the proposal of reusing eggshell and ESM as adsorbents has increased in recent years. Several works have been conducted to test the ability of these materials to remove dyes or ions from solution, as they might be used as low-cost adsorbents for water and wastewater decontamination. Vijayaraghavan et al. [112] investigated its ability to remove copper from aqueous solution in an up-flow packed column. The sorption performance of eggshell in the column was examined by varying the bed height $(15-25 \mathrm{~cm})$ and flow rate $(5-20 \mathrm{ml} / \mathrm{min})$. The column was regenerated using $0.01 \mathrm{M}$ EDTA solution and sorption-desorption studies were carried out for five cycles. This study showed that eggshell is an effective sorbent for copper removal. Both bed height and flow rate affected the copper sorption characteristics of the eggshell. The column regeneration studies indicated that the reusability of eggshell for copper removal is a viable solution. Earlier research had shown that ESM accumulates and eliminates various heavy metal ions from dilute aqueous solutions with a high affinity and in a short contact time, depending on the $\mathrm{pH}$ and other
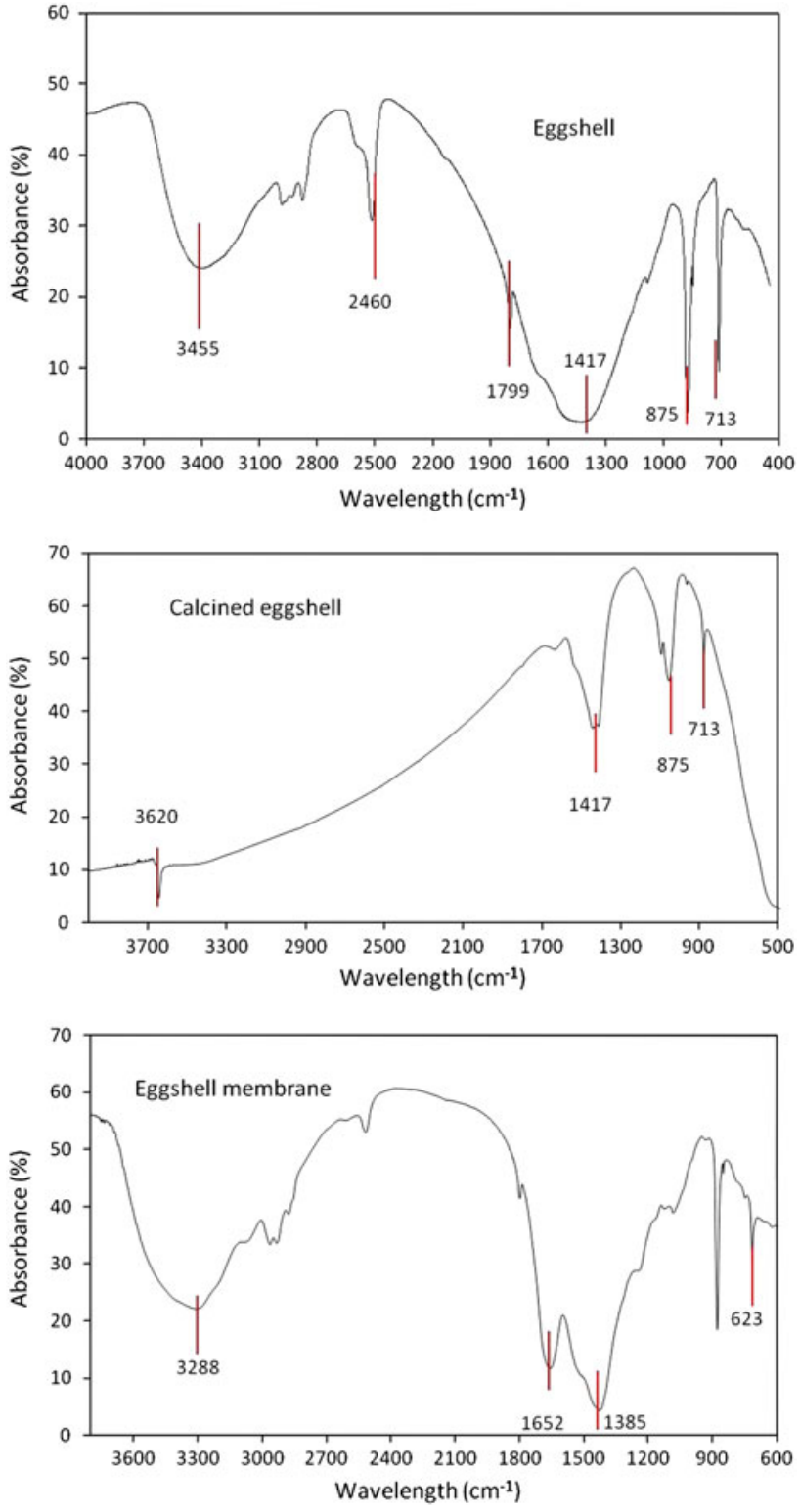

Fig. 2 FTIR spectra of eggshell, calcined eggshell and eggshell membrane particles

characteristics of the individual ion [117]. In this study, Suyama and colleagues reported that, under certain conditions, the level of precious ions (Au, Pt, and Pd) accumulation on the egg shell membrane (ESM) approaches 55, 
25 , and $22 \%$ of dry weight of ESM, respectively. Also, the uranium uptake reached almost $30 \%$ of the ESM dry weight. These experiments suggested that ESM could be promising to use for the purpose of removal and/or recovery of metals and water pollution control. Based on this study, Shoji and colleagues have successfully prepared a bead-type adsorbent from greatly swollen eggshell membrane-conjugated chitosan beads [133]. Competitive adsorption experiments have been performed in mixed solutions containing various metal ions. Experiments suggested that chitosan beads could take up gold ions with great capacity and selectivity by conjugation with eggshell membrane. It was reported by authors that, under certain conditions, the selective removal of gold and copper in a mixture of gold and copper ions by egg shell membraneconjugated chitosan beads was 100 and $2 \%$, respectively, suggesting a promising application to the recovering of gold in wastewater from various industries, such as electroplating. Selective actinide ion recovery from dilute, aqueous waste streams is an important problem. The recovery of uranium (U) and thorium (Th) by various animal biopolymers was examined by Ishikawa and colleagues [121, 134]. Of four species of biopolymers tested, a high uptake of uranium (U) and thorium (Th) was found in hen eggshell membrane (ESM) and silk proteins, with the maximum uranium and thorium recovery exceeding 98 and 79\%, respectively. The uptake of $U$ and Th was significantly affected by the $\mathrm{pH}$ of the solution, with he optimum $\mathrm{pH}$ values being, respectively, 6 and 3 for the uptake of $U$ and Th. Tested ESM and silk proteins were effective and selective for removing each metal by controlling $\mathrm{pH}$ and temperature of the solution. In addition, their adsorption capacities increased as salt concentration increased. It was found that, in multimetal systems, the order of sorption of ESM proteins was preferential: $\mathrm{U}>\mathrm{Cu}>\mathrm{Cd}>\mathrm{Mn}>\mathrm{Pb}>\mathrm{Th}>\mathrm{Ni}>\mathrm{Co}>\mathrm{Zn}$ at $\mathrm{pH} 6$ and $\mathrm{Th}>\mathrm{U}>\mathrm{Cu}>\mathrm{Pb}>\mathrm{Cd}>\mathrm{Mn}>\mathrm{Co}>\mathrm{Ni}=\mathrm{Zn}$ at $\mathrm{pH} 3$. It was concluded by the authors that these biopolymers appear to have potential for use in a commercial process for actinide recovery from actinide-containing wastewater. The use of eggshell and eggshell membranes as adsorbents for the removal of reactive dye from aqueous solutions was also investigated by Pramanpol and Nitayapat [135]. The adsorption characteristics of C.I. Reactive Yellow 205 by various components of eggshells were investigated by fitting the experimental data to Freundlich and Langmuir isotherms. The authors found that ESM had a much larger (10 to 27-fold) capacity to adsorb the dye than did the other components. Additionally it was reported that an initial $\mathrm{pH}$ range of dye solutions varying from 4 to 9 did not influence significantly the adsorption of dye by eggshell with membrane and the highest value of adsorption capacity was observed at the temperature of $35^{\circ} \mathrm{C}$. The extent of adsorption of the dye was related directly to the surface area of the adsorbent. The results presented in that work, have demonstrated clearly that eggshell with its attached membrane is a potentially useful material to be used for the removal of reactive dyes from industrial wastewater. In a recent study Maruyama et al. [136] investigated the recovery of $\mathrm{Au} 3+$ and $\mathrm{Pd} 2+$ from actual solutions containing metal ions produced in an industrial setting. Adsorption experiments were carried out using the egg-shell membrane as an adsorbent, due to its high performance for selective adsorption and its insolubility in an aqueous solution at a variety of $\mathrm{pH}$ values. After adsorption, the biomass adsorbing metal ions were charred, and the bound metal ions were redissolved in aqua regia for recovery. The authors found that the egg-shell membrane are able to adsorb Au3 + in the copper refining solution, while the biomass hardly adsorbed $\mathrm{Pt}$ and $\mathrm{Cu}$ ions. The sample solution contained many metal ions and $\mathrm{HCl}(2 \mathrm{M})$. The high ionic strength created could have prevented the adsorption of $\mathrm{Pt}$ ions. The adsorption ratio of Pd ions was relatively low, which can be explained by its low initial concentration and by the insufficient amount of biomass compared to the metal ions. Indeed, the adsorption ratio increased as the amount of biomass increased. Based on the redissolved Au ions it was stated that almost $165 \mathrm{~g}$ Au per $\mathrm{kg}$ biomass was recovered at the end of the experiment. This recycling procedure would be suitable for potential applications, because of its simplicity and of no other specific materials needed. Recently, Tsai et al. [137] studied the main physical and chemical characteristics of the hen eggshell and eggshell membrane particles. They have also evaluated the applicability of common isotherm models (i.e., Langmuir and Freundlich) based on the adsorption capacities from the removal of methylene blue from aqueous solution at $25^{\circ} \mathrm{C}$. This study revealed, for the conditions tested that the Freundlich model yielded a somewhat better fit than the Langmuir model. It was also found that an increase in the adsorption temperature from 15 to $45^{\circ} \mathrm{C}$ significantly enhanced the adsorption capacity of the dye acid orange 51, revealing that the adsorption might be endothermic or chemisorption. A similar study was performed by Ghani and coworkers, whom investigated the potential of eggshell powder as a low-cost adsorbent for methylene blue removal, concluding that this material could be efficiently employed for removal of colour and dyes from water and wastewater at low concentration [138]. Considering sustainability in the waste management we are looking for alternative solutions, which allow transforming the waste product into saleable items. The main goal of our project is the development of a new and innovative process for the treatment and valorization of the egg shell residue, which shall result in the obtainment of a lowcost adsorbent for water and wastewater decontamination. For this purpose, the adsorption kinetics of the material will be carefully addressed and the design and development of a filtration prototype will also be encompassed. We expected that this new product, very attractive from both the chemical and 
economical perspectives, should be able to replace the systematic use of activated carbon in the treatment of wastewater and gas emissions. Finally, it is foreseen the construction and assembling of a pilot plant unit able to treat 200 ton of residues per year and acting, at the same time, as a technology demonstration unit.

\section{Final Remarks}

The literature revealed that the main drawback associated with the adsorption of pollutants is, normally, the high cost of traditional adsorbents such as activated carbons. This is the driven force for the increase in production and utilization of low cost-adsorbents. It is worth to note that some materials can be used as adsorbents with little or no pretreatment and can therefore be manufactured at low cost. Certain waste products from industrial and agricultural operations, natural materials and biosorbents represent potentially economical alternative adsorbents. With this respect, the literature survey results and the methods discussed above lead us to the conclusion that the use of eggshell and eggshell membranes as adsorbent materials can give fruitful results. However, despite a great number of papers have been published on low cost sorbents, there is a little information containing a fully characterized comparative study between biosorbents. Although much as already been achieved in the area of low cost adsorbents, much still need to be done. Herein, we consider that our work will provide relevant information about important issues as the prediction of the performance of adsorbent process in real industrial effluents under a range of operating conditions and to demonstrate the use of inexpensive adsorbents at an industrial scale.

\section{References}

1. Bai, R.S., Abraham, T.E.: Studies on chromium(VI) adsorptiondesorption using immobilized fungal biomass. Biores. Technol. 87, 17-26 (2003)

2. Pandey, A., Bera, D., Shukla, A., Ray, L.: Potential of agarose for biosorption of $\mathrm{Cu}(\mathrm{II})$ in aqueous system. Am. J. Biochem. Biotech. 3, 55-59 (2007)

3. Malik, P.K.: Use of activated carbons prepared from sawdust and rice-husk for adsorption of acid dyes: a case study of Acid Yellow 36. Dyes Pigm. 56, 239-249 (2003)

4. Mahmoodi, N.M., Arami, M., Yousefi Limaee, N., Salman Tabrizi, N.: Decolorization and aromatic ring degradation kinetics of Direct Red 80 by UV oxidation in the presence of hydrogen peroxide utilizing $\mathrm{TiO} 2$ as a photocatalyst. Chem. Eng. J. 112, 191-196 (2005)

5. Mahmoodi, N.M., Arami, M.: Bulk phase degradation of Acid Red 14 by nanophotocatalysis using immobilized titanium (IV) oxide nano particles. J. Photochem. Photobiol. A Chem. 182, 60-66 (2006)
6. Mahmoodi, N.M., Arami, M., Yousefi Limaee, N.: Photocatalytic degradation of triazinic ring-containing azo dye (reactive red 198) by using immobilized $\mathrm{TiO} 2$ photoreactor: bench scale study. J. Hazard. Mater B 133, 113-118 (2006)

7. Mahmoodi, N.M., Arami, M., Yousefi Limaee, N., Salman Tabrizi, N.: Kinetics of heterogeneous photocatalytic degradation of reactive dyes in an immobilized $\mathrm{TiO} 2$ photocatalytic reactor. J. Colloid Interface Sci. 295, 159-164 (2006)

8. Ozcan, A.S., Erdem, B., Ozcan, A.: Adsorption of Acid Blue 193 from aqueous solutions onto BTMA-bentonite. Colloids Surf. A 266, 73-81 (2005)

9. Crini, G., Peindy, H.N.: Adsorption of C.I. Basic Blue 9 on cyclodextrin-based material containing carboxylic groups. Dyes Pigm. 70, 204-211 (2006)

10. Crini, G.: Non-conventional low-cost adsorbents for dye removal: a review. Bioresour. Technol. 97, 1061-1085 (2006)

11. Gupta, V.K., Mittal, A., Kurup, L., Mittal, J.: Adsorption of a hazardous dye, erythrosine, over hen feathers. J. Colloid Interface Sci. 304, 52-57 (2006)

12. Crini, G., Badot, P.-M.: Application of chitosan, a natural aminopolysaccharide, for dye removal from aqueous solutions by adsorption processes using batch studies: a review of recent literature. Prog. Polym. Sci. 39, 399-447 (2008)

13. Pollard, S.J.T., Fowler, G.D., Sollars, C.J., Perry, R.: Low-cost adsorbents for waste and wastewater treatment: a review. Sci. Total Environ. 116, 31-52 (1992)

14. Gupta, V.K., Suhas, : Application of low-cost adsorbents for dye removal-A review. J. Environ. Manage. 90, 2313-2342 (2009)

15. Bhatnagar, A., Sillanpää, M.: Utilization of agro-industrial and municipal wastes as potential adsorbents for water treatment-A review. Chem. Eng. J. 157, 277-296 (2010)

16. Gupta, V.K., Rastogi, A., Nayak, A.: Biosorption of nickel onto treated alga (Oedogonium hatei): application of isotherm and kinetic models. J. Colloid Interface Sci. 342, 533-539 (2010)

17. Gupta, V.K., Carrott, P.J.M., Ribeiro Carrott, M.M.I., Suhas, : Low cost adsorbents: growing approach to wastewater treatment-A review. Crit. Rev. Environ. Sci Technol. 39, 783-842 (2009)

18. Yoshida, H., Takemori, T.: Adsorption of direct dye on crosslinked chitosan fiber: breakthrough curve. Water Sci. Technol. 35, 29-37 (1997)

19. Annadurai, G.: Design of optimum response surface experiments for adsorption of direct dye on chitosan. Bioprocess Eng. 23, 451-455 (2000)

20. Prado, A.G.S., Torres, J.D., Faria, E.A., Dias, S.C.L.: Comparative adsorption studies of indigo carmine dye on chitin and chitosan. J. Colloid Interface Sci. 277, 43-47 (2004)

21. Annadurai, G., Ling, L.Y., Lee, J.-F.: Adsorption of reactive dye from an aqueous solution by chitosan: isotherm, kinetic and thermodynamic analysis. J. Hazard. Mater. 152, 337-346 (2008)

22. Rattanaphani, S., Chairat, M., Bremner, J.B., Rattanaphani, V.: An adsorption and thermodynamic study of lac dyeing on cotton pretreated with chitosan. Dyes Pigm. 72, 88-96 (2007)

23. Ellis, J., Korth, W.: Removal of geosmin and methylisoborneol from drinking water by adsorption on ultrastable zeolite-Y. Water Res. 27, 535-539 (1993)

24. Okolo, B., Park, C., Keane, M.A.: Interaction of phenol and chlorophenols with activated carbon and synthetic zeolites in aqueous media. J. Colloid Interface Sci. 226, 308-317 (2000)

25. Metes, A., Kovacevic, D., Vujevic, D., Papic, S.: The role of zeolites in wastewater treatment of printing inks. Water Res. 38, 3373-3381 (2004)

26. Motsi, T., Rowson, N.A., Simmons, M.J.H.: Adsorption of heavy metals from acid mine drainage by natural zeolite. Int. J. Miner. Process. 92, 42-48 (2009) 
27. Wang, S., Peng, Y.: Natural zeolites as effective adsorbents in water and wastewater treatment. Chem. Eng. J. 156, 11-24 (2010)

28. McKay, G., Otterburn, M.S., Aga, J.A.: Fuller earth and fired clay as adsorbents for dyestuffs-equilibrium and rate studies. Water Air Soil Pollut. 24, 307-322 (1985)

29. Nassar, M.M., Elgeundi, M.S.: Comparative cost of color removal from textile effluents using natural adsorbents. J. Chem. Technol. Biotechnol. 50, 257-264 (1991)

30. Espantaleon, A.G., Nieto, J.A., Fernandez, M., Marsal, A.: Use of activated clays in the removal of dyes and surfactants from tannery waste waters. Appl. Clay Sci. 24, 105-110 (2003)

31. Alkan, M., Demirbas, O., Dogan, M.: Adsorption kinetics and thermodynamics of an anionic dye onto sepiolite. Microporous Mesoporous Mater. 101, 388-396 (2007)

32. Ozcan, A.S., Ozcan, A.S.: Adsorption of acid dyes from aqueous solutions onto acid-activated bentonite. J. Colloid Interface Sci. 276, 39-46 (2004)

33. Ozcan, A., Ozcan, A.S.: Adsorption of Acid Red 57 from aqueous solutions onto surfactant-modified sepiolite. J. Hazard. Mater. 125, 252-259 (2005)

34. Gupta, V.K., Jain, R., Varshney, S.: Electrochemical removal of hazardous dye Reactofix Red 3 BFN from industrial effluents. J. Colloid Interface Sci. 312, 292-296 (2007)

35. Gupta, V.K., Rastogi, A., Dwivedi, M.K., Mohan, D.: Process development for the removal of zinc and cadmium from wastewater using slag-A blast-furnace waste material. Sep. Sci. Technol. 32, 2883-2912 (1997)

36. Namasivayam, C., Arasi, D.: Removal of congo red from wastewater by adsorption onto waste red mud. Chemosphere 34, 401-417 (1997)

37. Wang, S., Boyjoo, Y., Choueib, A., Zhu, Z.H.: Removal of dyes from aqueous solution using fly ash and red mud. Water Res. 39, 129-138 (2005)

38. Gupta, V.K., Ali, I., Saini, V.K.: Removal of rhodamine B, fast green, and methylene blue from wastewater using red mud, an aluminum industry waste. Ind. Eng. Chem. Res. 43, 1740-1747 (2004)

39. Tor, A., Cengeloglu, Y.: Removal of congo red from aqueous solution by adsorption onto acid activated red mud. J. Hazard. Mater. 138, 409-415 (2006)

40. Gupta, V.K., Ali, I., Saini, V.K.: Removal of chlorophenols from wastewater using red mud: an aluminum industry waste. Environ. Sci. Technol. 38, 4012-4018 (2004)

41. Gupta, V.K., Sharma, S.: Removal of Cadmium and Zinc from aqueous solutions using red mud. Environ. Sci. Technol. 36, 3612-3617 (2002)

42. Jain, A.K., Gupta, V.K., Bhatnagar, A., Suhas: Utilization of industrial waste products as adsorbents for the removal of dyes. J. Hazard. Mater. B101, 31-42 (2003)

43. Gupta, V.K., Mittal, A., Krishnan, L., Gajbe, V.: Adsorption kinetics and column operations for the removal and recovery of malachite green from wastewater using bottom ash. Sep. Purif. Technol. 40, 87-96 (2004)

44. Gupta, V.K., Ali, I., Saini, V.K.: Adsorption studies on the removal of Vertigo Blue 49 and Orange DNA13 from aqueous solutions using carbon slurry developed from a waste material. J. Colloid Interface Sci. 315, 87-93 (2007)

45. Gupta, V.K., Srivastava, S.K., Mohan, D.: Equilibrium uptake, sorption dynamics, process optimization, and column operations for the removal and recovery of malachite green from wastewater using activated carbon and activated slag. Ind. Eng. Chem. Res. 36, 2207-2218 (1997)

46. Gupta, V.K., Ali, I., Sushas, Saini, V.K.: Adsorption of 2, 4-D and carbofuran pesticides using fertilize rand steel industry wastes. J. Colloid Interface Sci. 299, 556-563 (2006)
47. Gupta, V.K., Ali, I.: Removal of endosulfan and methoxychlor from water on carbon slurry. Environ. Sci. Technol. 42, 766-770 (2008)

48. Gupta, V.K., Rastogi, A., Nayak, A.: Adsorption studies on the removal of hexavalent chromium from aqueous solution using a low cost fertilizer industry waste material. J. Colloid Interface Sci. 342, 135-141 (2010)

49. Gupta, V.K., Ali, I., Saini, V.K.: Defluoridation of wastewaters using waste carbon slurry. Water Res. 41, 3317-3326 (2007)

50. Gupta, V.K., Mittal, A., Jain, R., Mathur, M., Sikarwar, S.: Adsorption of Safranin-T from wastewater using waste materials-activated carbon and activated rice husk. J. Colloid Interface Sci. 303, 80-86 (2006)

51. Gupta, V.K., Jain, R., Varshney, S.: Removal of reactofix golden yellow 3 RFN from aqueous solution using wheat husk-an agricultural waste. J. Haz. Mat. 142, 443-448 (2007)

52. Gupta, V.K., Jain, R., Varshney, S., Saini, V.K.: Removal of reactofix Navy Blue 2 GFN from aqueous solutions using adsorption techniques. J.Colloid Interface Sci. 307, 326-332 (2007)

53. Gupta, V.K., Jain, C.K., Ali, I., Chandra, S., Agarwal, S.: Removal of lindane and malathion from wastewater using bagasse fly ash-a sugar industry waste. Water Res. 36, 2483-2490 (2002)

54. Gupta, V.K., Ali, I.: Removal of DDD and DDE from wastewater using bagasse fly ash, a sugar industry waste. Water Res. 35, 33-40 (2001)

55. Gupta, V.K., Mohan, D., Sharma, S., Park, K.T.: Removal of chromium (VI) from electroplating industry wastewater using bagasse fly ash-a sugar Industry waste material. Environmentalist 19, 129-136 (1999)

56. Ahmedna, M., Marshall, W.E., Rao, R.M.: Production of granular activated carbons from selected agricultural by-products and evaluation of their physical, chemical and adsorption properties. Bioresour. Technol. 71, 113-123 (2000)

57. Bulut, Y., Baysal, Z.: Removal of $\mathrm{Pb}(\mathrm{II})$ from wastewater using wheat bran. J. Environ. Manag. 78, 107-113 (2006)

58. Ajmal, M., Rao, R.A.K., Ahmad, R., Ahmad, J.: Adsorption studies on Citrus reticulate (fruit peel of orange): removal and recovery of $\mathrm{Ni}(\mathrm{II})$ from electroplating wastewater. J. Hazard. Mater. 79, 117-131 (2000)

59. Mittal, A., Gupta, V.K., Malviya, A., Mittal, J.: Process development for the batch and bulk removal and recovery of a hazardous, water-soluble azo dye (Metanil Yellow) by adsorption over waste materials (Bottom Ash an De-Oiled Soya). J. Hazard. Mater. 151, 821-832 (2008)

60. Mittal, A., Mittal, J., Malviya, A., Gupta, V.K.: Adsorptive removal of hazardous anionic dye "Congo red" from wastewater using waste materials and recovery by desorption. J. Colloid Interface Sci. 340, 16-26 (2009)

61. Mittal, A., Mittal, J., Malviya, A., Kaur, D., Gupta, V.K.: Decoloration treatment of a hazardous triarylmethane dye, light green SF (yellowish) by waste material adsorbents. J. Colloid Interface Sci. 342, 518-527 (2010)

62. Mittal, A., Mittal, J., Malviya, A., Gupta, V.K.: Removal and recovery of Chrysoidine Y from aqueous solution by waste materials. J. Colloid Interface Sci. 344, 497-507 (2010)

63. Gupta, V.K., Ali, I., Saini, V.K., Van Gerven, T., Van der Bruggen, B., Vandecasteele, C.: Removal of dyes from wastewater using bottom ash. Ind. Engg. Chem. Res. 44, 3655-3664 (2005)

64. Mittal, A., Kaur, D., Malviya, A., Mittal, J., Gupta, V.K.: Adsorption studies on the removal of colouring agent phenol red from wastewater using waste materials as adsorbents. J. Colloid Interface Sci. 337, 345-354 (2009)

65. Gupta, V.K., Mittal, A., Malviya, A., Mittal, J.: Adsorption of Carmoisine A from wastewater using waste materials-bottom 
ash and de-oiled soya. J. Colloid Interface Sci. 355, 24-33 (2009)

66. Gupta, V.K., Mittal, A., Gajbe, V., Mittal, J.: Adsorption of basic fuchsin using waste materials-bottom ash and de-oiled soya as adsorbents. J. Colloid Interface Sci. 319, 30-39 (2008)

67. Jain, A.K., Gupta, V.K., Bhatnagar, A., Shubhi, J., Suhas, : A comparative assessment of adsorbents prepared from industrial wastes for the removal of cationic dye. J. Indian Chem. Soc. 80, 267-270 (2003)

68. Allen, S.J., Koumanova, B.: Decolourisation of water/wastewater using adsorption (Review). J. University Chem. Tech. Metal. 40, 175-192 (2005)

69. Parande A.K., Sivashanmugam A., Beulah H., Palaniswamy N.: Performance evaluation of low cost adsrobents in reduction of COD in sugar industrial effluent. J. Hazard. Mater. 168, 800-805 (2009). doi:10.1016/j.jhazmat.2009.02.098

70. Bansal, R.C., Donet, J.-B., Fritz, S.: Active Carbon. Marcel Dekker, New York. (1988)

71. Carrott, P.J.M., Ribeiro Carrott, M.M.L., Mourao, P.A.M., Lima, R.P.: Preparation of activated carbons from cork by physical activation in carbon dioxide. Adsorpt. Sci. Technol. 21, 669-681 (2003)

72. Carrott, P.J.M., Mourao, P.A.M., Ribeiro Carrott, M.M.L., Goncalves, E.M.: Separating surface and solvent effects and the notion of critical adsorption energy in the adsorption of phenolic compounds by activated carbons. Langmuir 21, 11863-11869 (2005)

73. Hassler, J.W.: Activated Carbon. Chemical Publishing Company, Inc., New York. (1963)

74. Lillo-Rodenas, M.A., Marco-Lozar, J.P., Cazorla-Amoros, D., Linares-Solano, A.: Activated carbons prepared by pyrolysis of mixtures of carbon precursor/alkaline hydroxide. J. Anal. Appl Pyrolysis 80, 166-174 (2007)

75. Bansal, R.C., Goyal, M.: Activated Carbon Adsorption. Taylor \& Francis Group, Boca Raton. (2005)

76. Phan, N.H., Rio, S., Faur, C., Le Coq, L., Le Cloirec, P., Nguyen, T.H.: Production of fibrous activated carbons from natural cellulose (jute, coconut) fibers for water treatment applications. Carbon 44, 2569-2577 (2006)

77. Kurniawan, T.A., Chan, G.Y.S., Lo, W.-H., Badel, S.: Comparisons of low-cost adsrobents for treating wastewaters laden with heavy metals. Sci. Total Environ. 366, 409-426 (2006)

78. Weber Jr., W.J., Hopkins, C.B., Bloom Jr., R.: Physicochemical treatment of wastewater. J. Water Pollut. Control Fed. 42, 83-89 (1970)

79. Najm, I.N., Snoeyink, V.L., Lykins, B.W.J., Adams, J.Q.: Using powdered activated carbon: a critical review. J. Am. Water Works Assoc. 83, 65-76 (1991)

80. Stenzel, M.H.: Remove organics by activated carbon adsorption. In: Nalven, G.F. (ed.) Practical Engineering Percpectives The Environment: Air-Water and Soil, pp. 237-244. American Institute of Chemical Engineers, New York (1997)

81. David, A.P., Huang, C.P.: Adsorption of some substituted phenols onto hydrous CdS(s). Langmuir 6, 857-862 (1990)

82. Liu, J.C., Huang, C.P.: Adsorption of some substituted phenols onto hydrous ZnS(s). J. Colloid Interface Sci. 153, 167-176 (1992)

83. Pollard, S.J.T., Christopher, S.J., Rogger, P.: A clay carbon absorbent derived from spent bleaching earth: surface characterization and absorption of chlorophenols from aqueous solution. Carbon 30, 639-646 (1992)

84. Haderlein, S.B., Schwarzenbach, C.J., Perry, R.: Adsorption of substituted nitrobenzenes and nitro-phenols to mineral surfaces. Environ. Sci. Technol. 27, 316-326 (1993)

85. Reddy, K.R.: Removal of dialkylphenols from aqueous effuents by selective absorption in a novel, large pore, silica molecular sieve. J. Chem. Soc. Chem. Comm. 24, 559-560 (1993)
86. Dentel, S.K., Bottero, J.Y., Khatib, K., Demougeot, H., Duguet, J.P., Anselme, C.: Sorption of tannic acid, phenol and 2, 4, 5-trichlorophenol on organoclays. Water Res. 29, 1273-1280 (1995)

87. Streat, M., Patrick, J.W., Perez Comparro, M.J.: Sorption of phenol and p-chlorophenol from water using conventional and novel activated carbons. Water Res. 29, 467-472 (1995)

88. Daifullah, A.E., Reefy, S.E., Gad, H.: Adsorption of p-nitrophenol on inshas incinerator ash and on pyrolysis residue of animal bones. Adsor. Sci. Technol. 15, 485-496 (1997)

89. Gupta, V.K., Sharama, S., Yadav, I.S., Mohan, D.: Utilization of bagasse fly ash generated in the sugar industry for the removal and recovery of phenol and p-nitrophenol from wastewater. J. Chem. Technol. Biotechnol. 71, 180-186 (1998)

90. Jashni, A.K., Narbaitz, R.M.: Impact of $\mathrm{pH}$ on the adsorption and desorption of kinetics of 2-nitro-phenol on activated carbons. Water Res. 31, 3039-3044 (1997)

91. Gupta, V.K., Srivastava, S.K., Tyagi, R.: Design parameters for the treatment of phenolic wastes by carbon columns (obtained from fertelizer waste material). Water Res. 34, 1543-1550 (2000)

92. Gupta, V.K., Ali, I.: Adsorbents for water treatment: Low cost alternatives to carbon. Encyclopedia of Surface and Colloid Science, 2nd edn, pp. 1-34 (2003)

93. Bailey, S.E., Olin, T.J., Bricka, R.M., Adrian, D.D.: A review of potentially low-cost sorbents for heavy metals. Water Res. 33, 2469-2479 (1999)

94. Webi, T.W., Chakravort, R.K.: Pore and solid diffusion models for fixed-bed adsorbers. AIChE J. 20, 228-238 (1974)

95. Babu, B.V., Gupta, S.: Modeling and simulation of fixed bed adsorption column: effect of velocity variation. J. Eng. Technol. 1, 60-66 (2005)

96. Bohart, G., Adams, E.: Some aspects of the behavior of charcoal with respect to chlorine. J. Am. Chem. Soc. 42, 523-545 (1920)

97. Cooney, D.O.: Adsorption Design for Wastewater Treatment. Lewis Publishers, Boca Raton, Florida (1999)

98. Clark, S.C., Lawler, D.F., Cushing, R.S.: Contact filtration: particle size and ripening. J. Am. Water Works Assoc. 84, 61-71 (1992)

99. McKay, G.: Use of Adsorbents for the Removal of Pollutants from Wastewaters. CRC Press, Boca Raton, Florida (1996)

100. Clark, S., Brown, P., Pitt, R.: Wastewater treatment using lowcost adsorbents and waste material. Proc. Water Environ. Fed. Ind. Waste 24, 11-34 (2000)

101. Park, D., Yun, Y.S., Lim, S.R., Park, J.M.: Kinetic analysis and mathematical modeling of $\mathrm{Cr}(\mathrm{VI})$ removal in a differential reactor packed with ecklonia biomass. J. Microbiol. Biotechnol. 16, 1720-1727 (2006)

102. Aksu, Z., Acikel, U., Kutsal, T.: Investigation of simultaneous biosorption of copper (II) and chromium (VI) on dried chlorella vulgaris from binary metal mixtures: application of multicomponent adsorption isotherms. Sep. Sci. Technol. 34, 501-524 (1999)

103. Ho, Y., Huang, C.T., Haung, H.W.: Equilibrium sorption isotherm for metal ions on tree fern. Process Biochem 37, 1421-1430 (2002)

104. Ho, Y.S., Mckay, G.: The kinetics of sorption of basic dyes from aqueous solution by sphagnum moss peat. Can. J. Chem. Eng. 76, 822-827 (1998)

105. Yu, B., Zhang, Y., Shukla, A., Shukla, S., Dorris, K.L.: The removal of heavy metals from aqueous solutions by sawdust adsorption-removal of lead and comparison of its adsorption with koper. J. Hazard. Mater. 84, 83-94 (2001)

106. Stadelman, W.J.: Eggs and egg products. In: Francis, F.J. (ed.) Encyclopedia of Food Science and Technology, pp. 593-599. John Wiley \& Sons, New York (2000) 
107. Poland, A.L., Sheldon, B.W.: Altering the thermal resistance of foodborne bacterial pathogens with an eggshell membrane waste by-product. J. Food Prot. 64, 486-492 (2001)

108. Tacon, A.G.J.: Utilisation of chick hatchery waste: the nutritional characteristics of day-old chicks and egg shells. Agric. Wastes 4, 335-343 (1982)

109. Kuh, S.E., Kim, D.S.: Removal characteristics of cadmium ion by waste egg shell. Environ. Technol. 21, 883-890 (2000)

110. Chojnacka, K.: Biosorption of Cr(III) ions by eggshells. J. Hazard. Mater. 121, 167-173 (2005)

111. Koumanova, B., Peeva, P., Allen, S.J., Gallagher, K.A., Healy, M.G.: Biosorption from aqueous solutions by eggshell membranes and Rhizopus oryzae: equilibrium and kinetic studies. J. Chem. Technol. Biotechnol. 77, 539-545 (2002)

112. Vijayaraghavan, K., Jegan, J., Jegan, J., Jegan, J.: Removal and recovery of copper from aqueous solution by eggshell in a packed column. Miner. Eng. 18, 545-547 (2005)

113. Tullett, S.G.: Egg shell formation and quality. In: Wells, R.G., Belyavin, C.G. (eds.) Egg Quality-Current Problems and Recent Advances, pp. 123-146. Butterworths, London (1987)

114. Parsons, A.H.: Structure of the eggshell. Poult. Sci. 61, 2013-2021 (1982)

115. Nakano, T., Ikawa, N.I., Ozimek, L.: Chemical composition of chicken eggshell and shell membranes. Poult. Sci. 82, 510-514 (2003)

116. Tsai, W.T., Yang, J.M., Lai, C.W., Cheng, Y.H., Lin, C.C., Yeh, C.W.: Characterisation and adsorption properties of eggshells and eggshell membrane. Bioresour. Technol. 97, 488-493 (2006)

117. Suyama, K., Fukazawa, Y., Umetsu, Y.: A new biomaterial, hen egg shell membrane, to eliminate heavy metal ion from their dilute waste solution. Appl. Biochem. Biotechnol. 45, 871-879 (1994)

118. Ishikawa, S.I., Suyama, K.: Recovery and refining of Au by gold-cyanide ion biosorption using animal fibrous proteins. Appl. Biochem. Biotechnol. 70, 719-728 (1998)

119. Allen, S.J., Gan, Q., Matthews, R., Johnson, P.A.: Comparison of optimised isotherm models for basic dye adsorption by kudzu. Bioresour. Technol. 88, 143-152 (2003)

120. Gota, M., Suyama, K.: Occlusion of transition ions by new adsorbents synthesized from plant polyphenols and animal fibrous proteins. Appl. Biochem. Biotechnol. 84-86, 1021-1038 (2000)

121. Ishikawa, S.I., Suyama, K., Arihara, K., Itoh, M.: Selective recovery of uranium and thorium ions from dilute aqueous solutions by animal biopolymers. Biol. Trace Elem. Res. 86, 227-236 (2002)

122. Ishikawa, S.I., Suyama, K., Arihara, K., Itoh, M.: Uptake and recovery of gold ions from electroplating wastes using eggshell membrane. Bioresour. Technol. 81, 201-206 (2002)
123. Xiao, D., Choi, M.M.F.: Aspartame optical biosensor with bienzyme-immobilized eggshell membrane and oxygen-sensitive optode membrane. Anal. Chem. 74, 863-870 (2002)

124. Yang, D., Qi, L., Ma, J.: Hierarchically ordered networks comprising crystalline $\mathrm{ZrO} 2$ tubes through sol-gel mineralization of eggshell membranes. J. Mater. Chem. 13, 1119-1123 (2003)

125. Choi, M.M.F., Yiu, T.P.: Immobilization of beef liver catalase on eggshell membrane for fabrication of hydrogen peroxide biosensor. Enzyme Microb. Technol. 34, 41-47 (2004)

126. Dean, J.A. In: McGraw-Hill (ed). Langes Handbook of Chemistry. pp. 4-33. New York (1987)

127. Busca G., Resini, C. In: Meyers, R.A. (ed). Vibrational spectroscopy for the analyses of geological and inorganic materials. Encyclopedia of Analytical Chemistry. pp. 10954-11008. Wiley, Chichester (2000)

128. Christmas, R.B., Harms, R.H.: Utilization of egg shells and phosphoric acids as a source of phosphorus and calcium in the diet of White Leghorn cockerels. Poult. Sci. 55, 264-267 (1976)

129. Rivera, E.M., Araiza, M., Brostow, W., Castano, V.M., DiazEstrada, J.R., Hernandez, R., Rodriguez, J.R.: Synthesis of hydroxyapatite from eggshells. Mater. Lett. 41, 128-134 (1999)

130. Rauch, W.: The influence of egg-shell porosity on the number of chickens hatched from incubating eggs. Poult. Sci. 31, 589-594 (1952)

131. Creger, C.R., Phillips, H., Scott, J.T.: Formation of an egg shell. Poult. Sci. 55, 1717-1723 (1976)

132. Garcia-Ruiz, J.M., Navarro, A.R., Kalin, O.: Textural analysis of eggshells. Mater. Sci. Eng. C3, 95-100 (1995)

133. Shoji, R., Miyazaki, T., Niinou, T., Kato, M., Ishii, H.: Recovery of gold by chicken egg shell membrane-conjugated chitosan beads. J. Mater. Cycles Waste Manag. 6, 142-146 (2004)

134. Ishikawa, S., Suyama, K., Satoh, I.: Biosorption of actinides from dilute waste actinide solution by egg-shell membrane. Appl. Biochem. Biotechnol. 77, 521-533 (1999)

135. Pramanpol, N., Nitayapat, N.: Adsorption of reactive dye by eggshell and its membrane. Kasetsart J. Nat. Sci. 40, 192-197 (2006)

136. Maruyama, T., Matsushita, H., Shimada, Y., Kamata, Y., Hanaki, M., Sonokawa, S., Kamiya, N., Goto, M.: Proteins and protein-rich biomass as environmentally friendly adsorbents selective for precious metal ions. Environ. Sci. Technol. 41, 1359-1364 (2007)

137. Tsai, W.T., Hsien, K.-J., Hsu, H.-C., Lin, C.-M., Lin, C.-M., Chiu, C.H.: Utilisation of ground eggshell waste as an adsorbent for the removal of dyes from aqueous solution. Bioresour. Technol. 99, 1623-1629 (2009)

138. Ghani, A.A., Santiagoo R., Johnson, A.C., Ibrahim, N., Selamat, S.: Dye removal from aqueous solution using egg shell powder. Proceedings Book. 1st International Conference on Sustainable Materials (IcoSM), pp. 109-111 (2007) 